\title{
INTELLECTUAL CAPITAL DISCLOSURE: STUDI KOMPARASI ANTARA UNIVERSITAS DI INDONESIA DAN MALAYSIA
}

\author{
Ihyaul Ulum, Andi Tenrisumpala, Endang Dwi Wahyuni. \\ Universitas Muhammadiyah Malang \\ E-mail: ihyaul.ulum5@gmail.com
}

\begin{abstract}
The aim of this study is to identify the intellectual capital disclosure practices of Indonesia and Malaysian universities. 5 best universities from Indonesia and Malaysia based on webometrics 2015 survey was used as the object of study. Intellectual capital component used in this study is a framework developed by Ulum (20I I) which consist of 46 items: 8 items human capital, 23 items structural capital, and 15 items relational capital. Mann-Whitney test with SPSS 21 was used to analyze the data. The results showed that there were no differences between universities in Indonesia and Malaysia in disclosing information about the IC through their website. Based on the amount of information disclosed, both universities in Indonesia and Malaysia were more likely to disclose information in a narrative format.

Keywords: Intellectual Capital Discolusure, University, Comparative Studies Indonesian and Malaysian
\end{abstract}

\begin{abstract}
Abstrak
Tujuan penelitian ini adalah untuk mengidentifikasi praktik pengungkapan informasi tentang intellectual capital (IC) pada website universitas di Indonesia dan Malaysia.. Penelitian ini menggunakan website 5 universitas terbaik di Indonesia dan Malaysia (versi webometrics survey 20I5) sebagai objek kajian. Komponen IC yang digunakan dalam kajian ini adalah framework yang dikembangkan oleh Ulum (20II) yang terdiri dari 46 items: 8 item human capital, 23 item structural capital, dan 15 item relational capital. Uji beda dilakukan dengan menggunakan MannWhitney test di dalam SPSS 21 . Hasil kajian menunjukkan bahwa tidak ada perbedaan diantara universitas-universitas di Indonesia dan Malaysia dalam mengungkapkan informasi tentang IC melalui website mereka. Dari sisi jumlah informasi yang diungkapkan, baik universitas di Indonesia maupun di Malaysia cenderung lebih banyak mengungkapkan informasi dalam format narasi.
\end{abstract}

Kata Kunci: Intellectual Capital Discolusure, Universitas, Studi komparasi Indonesia Malaysia

Diterima: 26 Desember 2015; Direvisi: 5 Februari 2016; Disetujui: 5 Maret 2016 


\section{PENDAHULUAN}

Dalam beberapa dekade terakhir, aset tidak berwujud dan intellectual capital (IC) telah menjadi isu tidak hanya bagi para akademisi, namun juga pemerintah, regulator, perusahaan, investor, dan stakeholder lainnya. Berbagai kajian telah dihasilkan tentang tema ini sejak akhir tahun 1990-an, bahkan setidaknya telah ada dua jurnal internasional yang khusus membahas tentang tema IC dan intangible, yaitu journal of intellectual capital dan journal of knowledge mangement.

Meskipun sebagian besar kajian tentang manajemen pengetahuan (knowledge management) dan IC selama ini lebih banyak fokus terhadap perusahaan swasta, namun belakangan mulai muncul ketertarikan untuk mengembangkannya dari organisasi swasta ke organisasi publik, misalnya universitas dan pusat penelitian. Perkembangan terakhir ini terkait dengan fakta bahwa tujuan utama universitas adalah memproduksi dan menyebarluaskan pengetahuan (Ramírez, 2013), dan investasi paling penting bagi universitas adalah di sektor penelitian dan pengembangan sumberdaya manusia. Meskipun faktanya input dan output utama universitas pada dasarnya adalah intangible, namun sangat sedikit instrumen untuk mengukur dan mengelolanya (Cañibano dan Sánchez, 2004).

Di sektor privat kajian tentang IC sudah cukup beragam, mulai dari kerangka konseptual, pengklasifikasian, hingga pengukurannya. Bahkan, Pulic (1998) juga telah menemukan formula untuk mengukur dampak dari keberadaan IC di dalam perusahaan yang diberi label Value Added Intellectual Coefficient (VAIC). VAIC inilah yang kemudian dikembangkan oleh Ulum (2015) menjadi Extended VAIC+, Modified VAIC, dan iB-VAIC (see: Ulum, 20I3, 20I4; Ulum et al., 20I4b, 20I4a).

Di sektor publik, khususnya pendidikan tinggi, belum banyak kajian terkait dengan pengelolaan modal intelektual. Padahal, pendidikan tinggi dianggap sebagai lembaga yang berperan penting dalam sistem inovasi nasional (Cañibano dan Sánchez, 2009). Tujuan utama pendidikan tinggi adalah menghasilkan dan menyebarluaskan pengetahuan, dan investasi paling penting bagi pendidikan tinggi adalah di sektor penelitian dan pengembangan sumber daya manusia yang merupakan bagian penting dari modal intelektual. 
Pendidikan tinggi dihadapkan pada meningkatnya permintaan dari pemilik (pemerintah, yayasan) dan masyarakat untuk transparan dalam pengelolaan keuangan, pengungkapan tentang aktivitas sosial dan ekonomi dari pendidikan tinggi tersebut (Leitner, 2002). Lebih lanjut Leitner (2002) menyatakan bahwa pendidikan tinggi saat ini sangat lambat dalam berinovasi.

Pendidikan tinggi tidak memiliki struktur pemilik seperti perusahaan swasta, akibatnya mereka tidak perlu untuk menghasilkan jenis laporan tahunan yang dibutuhkan oleh hukum komersial, tetapi mereka harus melaksanakan sistem akuntansi keuangan (Leitner, 2002). Lebih lanjut, Leitner (2002) menyatakan bahwa persiapan pelaporan IC untuk pendidikan tinggi cenderung lebih sulit dibanding industri lain karena pendidikan tinggi memiliki berbagai tujuan dan sasaran yang menentukan kinerja mereka.

Saat ini media informasi yang paling populer adalah internet, dengan adanya internet pengguna dapat menerima informasi dengan cepat, tepat, akurat dan efisien. Pendidikan tinggi juga memanfaatkan internet untuk menyebarluaskan informasi dan publikasinya untuk pengguna eksternal untuk jangka waktu tahunan, triwulan, teoritis dan real time. Berdasarkan hal tersebut official website dari pendidikan tinggi dapat dijadikan objek penelitian mengenai pengungkapan intellectual capital (IC).

Bezhani (2010) meneliti pada II9 pendidikan tinggi di Inggris yang terdaftar di The Sunday Times University Guide 2006 di situs web “TIMES” dengan menggunakan framework Intellectual Capital untuk pendidikan tinggi di Eropa. Hasilnya, pada kategori human capital, tertinggi adalah akademik dan staf penelitian. Structural capital terbanyak mengungkapkan tentang investasi dalam perpustakaan, dan relational capital paling banyak pengungkapannya adalah kerjasama mitra baru dan konferensi yang diselenggarakan.

Penelitian yang dilakukan oleh Ulum (2012) bertujuan untuk mengembangkan suatu kerangka kerja pengungkapan modal intelektual (ICD) yang relevan dengan pendidikan tinggi di Indonesia. Konsep ini akan sangat berguna bagi pendidikan tinggi untuk mengungkapkan informasi IC mereka baik melalui situs web atau laporan tahunan. Penelitian ini didasarkan pada kerangka kerja Leitner (2002) yang telah banyak digunakan dalam penelitian tentang IC di pendidikan tinggi. Metode yang 
digunakan dalam penelitian ini adalah dokumentasi, wawancara, dan pemeriksaan rekan. Hasilnya menunjukkan bahwa penelitian ini berhasil membangun satu set komponen IC yang relevan untuk pendidikan tinggi di Indonesia. Jumlah yang dihasilkan dari komponen IC adalah 46 item, lebih dari 7 item IC adalah komponen yang disusun oleh Leitner (2002).

Cahyuni et al. (2012) melakukan penelitian dengan membandingkan I3 pendidikan tinggi negeri dan 13 pendidikan tinggi swasta peraih Qs-Star di Indonesia. Hasil penelitian ini menunjukkan bahwa ada perbedaan dalam pengungkapan intellectual capital (IC) antara pendidikan tinggi negeri dan swasta. Pengungkapan intellectual capital (IC) di pendidikan tinggi negeri mengungkapkan rata- rata 17,65 item, di sisi lain pengungkapan intellectual capital (IC) di pendidikan tinggi swasta mengungkapkan rata-rata 9,35 item. Uji Mann-whitney menjelaskan skor Asymp. Sig. (2-tailed) adalah 0,005 yang menunjukkan adanya perbedaan. Hasilnya juga menunjukkan bahwa pendidikan tinggi negeri cenderung lebih banyak mengungkapkan intellectual capital (IC) dibanding pendidikan tinggi swasta.

Penelitian ini merupakan komparasi pengungkapan intellectual capital (IC) antara lima Pendidikan Tinggi terbaik Indonesia dan lima Pendidikan Tinggi terbaik Malaysia menurut survei webomatrics 2015 , dimana webomatrics adalah salah satu sistem untuk mengukur atau memberikan penilaian terhadap kemajuan seluruh pendidikan tinggi terbaik di dunia (World Class University) melalui official website pendidikan tinggi tersebut. Penelitian ini menggunakan komponen intellectual capital (IC) pendidikan tinggi yang dikonstruksi oleh Ulum (20I2) yang merupakan modifikasi komponen intellectual capital (IC) yang diadopsi dari Leitner (2002) Modifikasi tersebut dilakukan dengan mempertimbangkan standar Badan Akreditasi Nasional Pendidikan Tinggi (BAN-PT).

\section{METODE}

Penelitian ini merupakan penelitian komparasi, yaitu penelitian yang membandingkan dua (atau lebih) objek kajian dalam suatu topik/bidang (Ulum dan Juanda, 2016). Objek penelitian ini adalah 5 (lima) universitas terbaik - versi webometrics 2015 - di Indonesia dan Malaysia. Kelima universitas tersebut adalah: 
(I) Indonesia: Universitas Gadjah Mada, Institut Teknologi Bandung, Universitas Indonesia, Universitas Airlangga, dan Universitas Brawijaya; (2) Malaysia: University of Malaya, Universiti Teknologi Malaysia, Universiti Sains Malaysia, Universiti Putra Malaysia, dan Universiti Kebangsaan Malaysia. Content analysis dilakukan terhadap official website masing-masing universitas dengan periode pengamatan antara tanggal 22 November 2015 sampai dengan 22 Desember 2015.

Framework ICD yang digunakan adalah framework ICD untuk universitas terdiri dari 46 item - yang dikembangkan oleh Ulum (2012) yang merupakan modifikasi dari komponen-komponen IC-nya Leitner (2004) dan ketentuan akreditasi program studi yang ditetapkan oleh Badan Akreditasi Nasional Pendidikan Tinggi (BAN-PT). Berikut adalah 46 item ICD yang digunakan dalam penelitian ini:

\section{Human Capital}

I. Jumlah penuh waktu profesor

2. Jumlah dan jenis pelatihan

3. Jumlah dosen tetap

4. Jumlah dosen tidak tetap (dosen tamu,dosen luar biasa, dosen pakar)

5. Prestasi dosen (penghargaan, hibah, pendanaan program)

6. Kualifikasi (jumlah jabatan) dosen akademik

7. Kompetensi dosen akademik (jumlah jenjang pendidikan dosen SI,S2,S3)

8. Jumlah staf non-akademik (pustakawan, laboran, teknisi, operator)

\section{Structural Capital}

9. Investasi di perpustakaan media elektronik

10. Penghasilan dari lisensi

II. Jumlah lisensi yang diberikan

12. Pengukuran dan layanan laboratorium

13. Visi program studi

14. Misi program studi

15. Tujuan dan sasaran

16. Strategi pencapaian

17. Teknologi yang digunakan dalam pembelajaran

18. Silabus dan rencana pembelajaran 
19. Teknik pembelajaran

20. Sarana, prasarana, dana untuk pembelajaran

21. Sistem evaluasi pembelajaran (kehadiran dosen, mahasiswa

22. Sistem perwalian

23. Rata-rata masa studi

24. Jumlah dosen per siswa

25. Ratio Drop Out

26. Rata-rata mahasiswa per dosen pembimbing

27. Rata-rata jumlah pertemuan/pembimbing

28. Kualifikasi akademik dosen pembimbing

29. Ketersediaan panduan mekanisme pengerjaan tugas akhir

30. Target waktu penulisan tugas akhir

31. Jumlah lulusan/wisuda

\section{Relational Capital}

32. Jumlah penelitian pihak ke-3 hibah luar negeri

33. Jumlah penelitian pihak ke-3 Dikti

34. Para ilmuwan internasional di Universitas

35. Jumlah konfrensi yang diselenggarakan

36. Penelitian/pengabdian kepada masyarakat

37. Publikasi ilmiah di jurnal Internasional

38. Publikasi ilmiah di jurnal organisasi yang terakreditasi a

39. Publikasi ilmiah di jurnal lokal

40. Hits situs internet

4I. E-Learning

42. Jumlah prestasi dan reputasi akademik, minat dan bakat mahasiswa

43. Layanan kemahasiswaan

44. Layanan dan pendayagunaan lulusan

45. Perekaman data lulusan

46. Partisipasi lulusan dalam pengembangan akademik. 
Analisis data dilakukan dalam dua tahap, yaitu: Pertama, Content Analysis. Analisis ini dilakukan dengan memberikan checklist terhadap item IC yang diungkapkan pada official website masing-masing pendidikan tinggi. Setelah dilakukan checklist, tahapan berikutnya dilakukan penjumlahan terhadap item yang diungkapkan pada masing-masing pendidikan tinggi.

Pengungkapan informasi IC diberi bobot sesuai proyeksinya dengan menggunakan kode numerik (five way numerical coding system) sebagai berikut:

$$
\begin{aligned}
& 0=\text { item tidak diungkapkan } \\
& 1=\text { item diungkapkan dalam bentuk narasi } \\
& 2=\text { item diungkapkan dalam bentuk numerik } \\
& 3=\text { item diungkapkan dengan nilai moneter } \\
& 4=\text { item diungkapkan dalam bentuk grafik/gambar }
\end{aligned}
$$

Kedua, Mann-whitney test. Mann-whitney test merupakan salah satu uji nonparametrik yang sangat kuat dan merupakan uji alternatif dari uji parametrik $t$ test Ghozali (2006). Langkah-langkah pengujian mann-whitney yaitu dengan membandingkan jumlah item IC yang diungkapkan antara pendidikan tinggi di Indonesia dan pendidikan tinggi di Malaysia, dimulai dari human capital, structural capital, dan relational capital.

\section{HASIL DAN PEMBAHASAN}

Penelitian ini dilakukan pada tanggal 22 Nopember - 22 Desember 2015. Analisis pertama yang dilakukan adalah content analysis. Analisis ini digunakan untuk mengidentifikasi item IC yang diungkapkan pada official website pendidikan tinggi Indonesia dan Malaysia. Analisis ini dilakukan dengan cara pemberian checklist. Pemberian checklist dilakukan pada item yang diungkapkan di dalam official website pendidikan tinggi.

Dasar yang digunakan dengan memberikan nilai “I” jika item diungkapkan dalam bentuk narasi, nilai " 2 " jika item diungkapkan dalam bentuk numerik, nilai "3" jika item diungkapkan dengan nilai moneter, nilai “4” jika item diungkapkan dalam bentuk grafik/gambar dan “0” jika item tidak diungkapkan. 


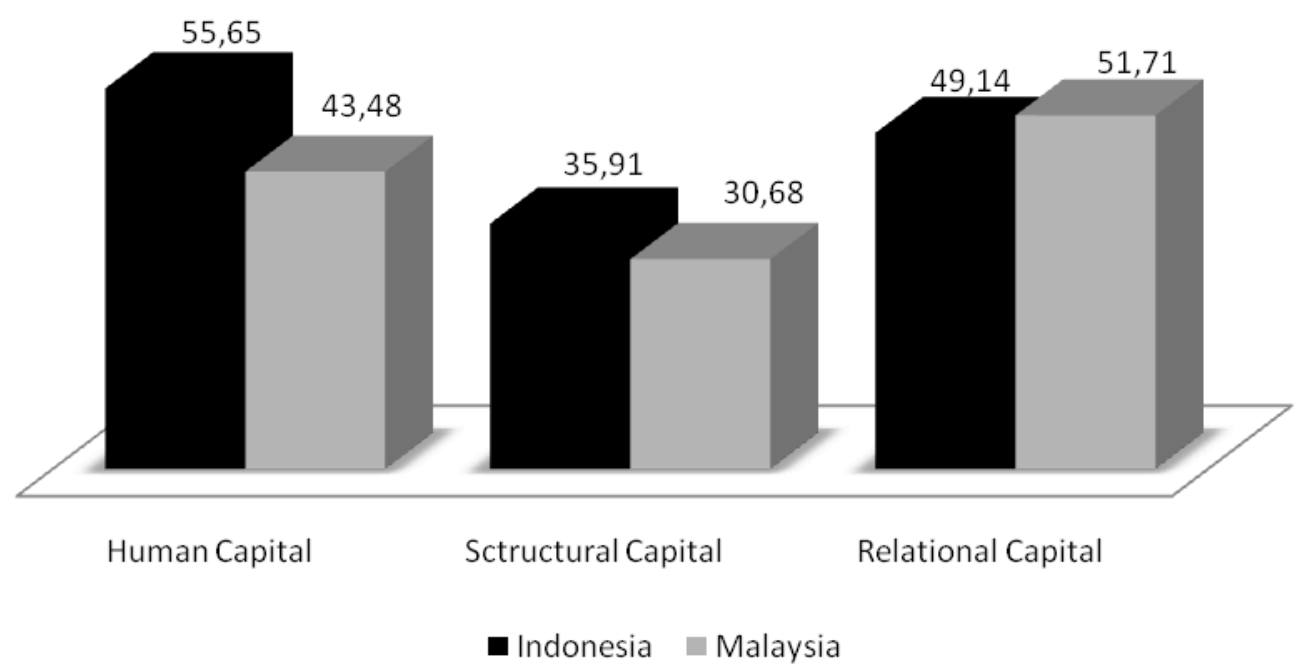

Figure I. Percentage of intellectual capital disclosure by Indonesia and Malaysia universities

Figure I menunjukkan bahwa persentase pengungkapan IC oleh perguruan tinggi di Indonesia dan Malaysia relatif sama. Indonesia unggul dalam kategori Human Capital dan Structural Capital, sementara Malaysia unggul jumlah pengungkapan IC untuk kategori Relational Capaital. Namun selisih diantara keduanya tidak cukup signifikan. Secara umum, pengungkapan IC oleh pendidikan tinggi Indonesia sudah cukup baik. Hal ini dibuktikan dengan adanya tiga pendidikan tinggi yang mengungkapkan lebih dari 50\% item IC. Sedikit berbeda, pendidikan tinggi di Malaysia yang mengungkapkan informasi IC lebih dari 50\% hanya satu universitas, sementara empat universitas lainnya menyajikan informasi kurang dari $50 \%$.

Figure 2 menyajikan informasi tentang cara (media) yang dipilih oleh pendidikan tinggi di Indonesia dalam menyajikan informasi tentang IC. Informasi tentang human capital (HC) lebih banyak disajikan dalam format narasi $(52,5 \%)$, kemudian dalam format angka (27,5\%), dan dalam bentuk gambar (20\%). Tidak ada satupun informasi tentang $\mathrm{HC}$ yang tidak diungkapkan, pun juga tidak ada informasi tentang $\mathrm{HC}$ yang disajikan dalam bentuk mata uang. 


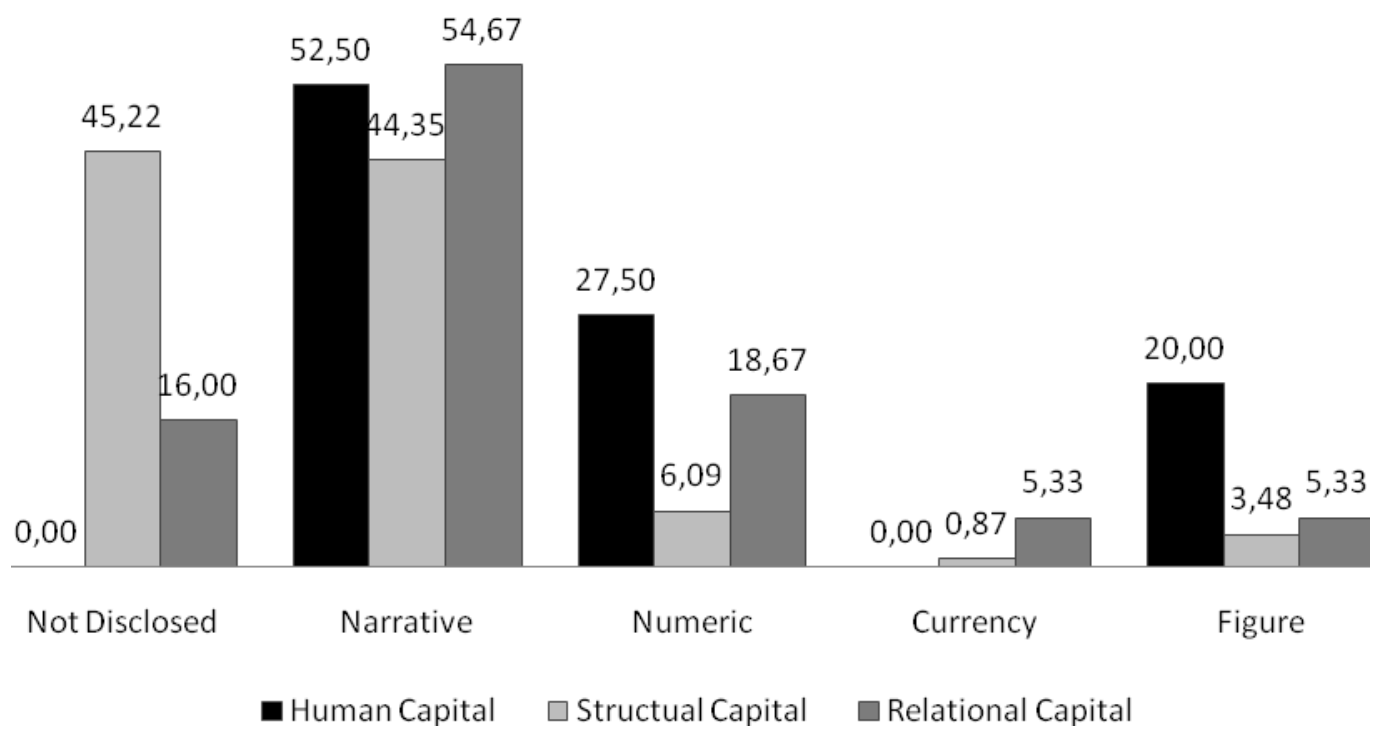

Figure 2. Type of intellectual capital disclosure by Indonesian universities

Seperti halnya informasi tentang HC, informasi tentang structural capital (SC) juga lebih banyak diungkapkan dalam format narasi (44,35\%). Namun, jenis informasi yang tidak diungkapkan juga cukup dominan (45,22\%). Proporsi yang relatif sama juga nampak dari pola pengungkapan informasi tentang relational capital (RC), dimana jenis informasi narasi lebih dominan.

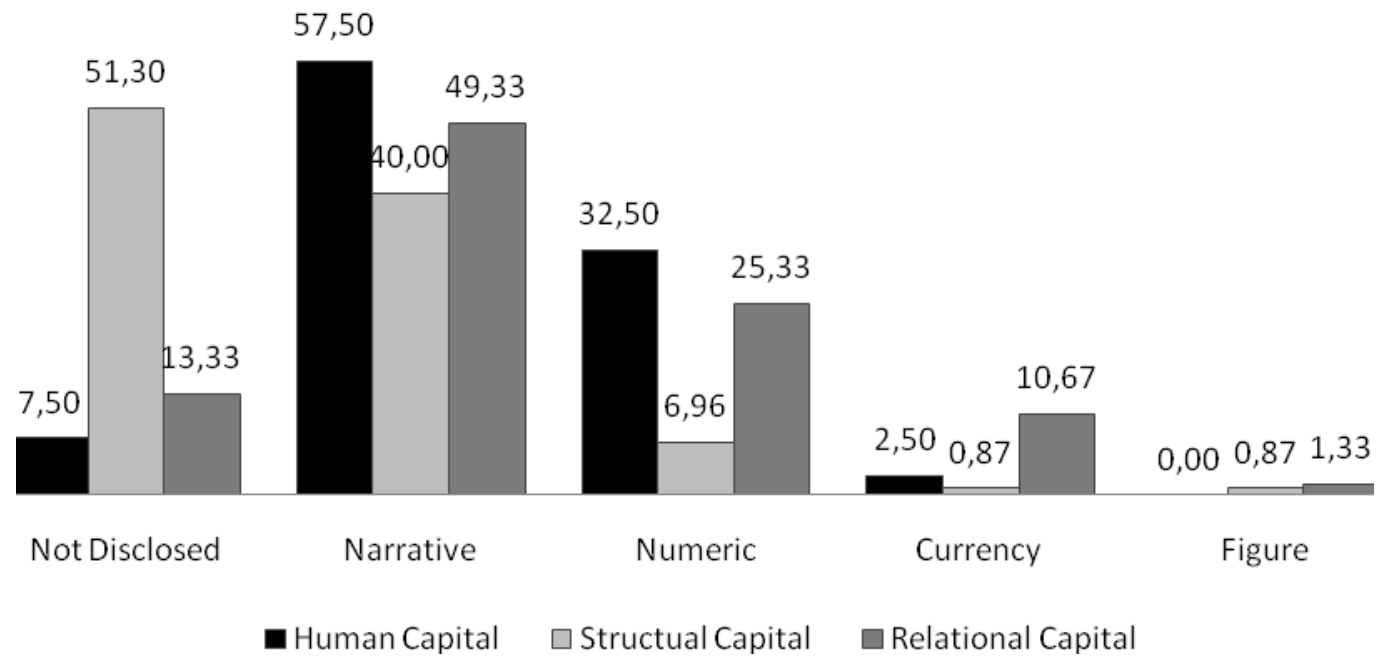

Figure 3. Type of intellectual capital disclosure by Malaysian universities 
Figure 3 menyajikan informasi tentang cara (media) yang dipilih oleh pendidikan tinggi di Malaysia dalam menyajikan informasi tentang IC. Relatif sama dengan pola pendidikan tinggi di Indonesia sebagaimana disajikan pada figure 2, informasi tentang human capital $(\mathrm{HC})$ lebih banyak disajikan dalam format narasi $(57,5 \%)$, kemudian dalam format angka (32,5\%), dan dalam bentuk mata uang $(2,5 \%)$. Tidak ada satupun informasi tentang HC yang disajikan dalam bentuk figure/grafik.

Seperti juga di Indonesia, informasi tentang structural capital (SC) pun lebih banyak diungkapkan dalam format narasi (40\%). Namun, jenis informasi yang tidak diungkapkan paling dominan (5I,3\%). Proporsi yang relatif sama juga nampak dari pola pengungkapan informasi tentang relational capital (RC), dimana jenis informasi narasi lebih dominan.

\section{Mann-Whitney Test}

Tabel 2 menggambarkan rata-rata pengungkapan IC pada pendidikan tinggi terbaik Indonesia lebih besar jika dibandingkan dengan pendidikan tinggi terbaik Malaysia menurut survei webomatrics 20I5. Hal ini dibuktikan dengan jumlah ratarata pengungkapan IC pada pendidikan tinggi Indonesia sebesar 6,30 atau 57\%, sedangkan rata-rata pengungkapan IC pada pendidikan tinggi Malaysia sebesar 4,70 atau $43 \%$.

Table 2. Hasil Uji Rata-Rata

\begin{tabular}{ccccc}
\hline \multicolumn{2}{c}{ PendidikanTinggi } & N & $\begin{array}{c}\text { Mean } \\
\text { Rank }\end{array}$ & $\begin{array}{c}\text { Sum of } \\
\text { Ranks }\end{array}$ \\
\hline IC & Indonesia & 5 & 6,30 & 31,50 \\
& Malaysia & 5 & 4,70 & 23,50 \\
& Total & 10 & & \\
\hline
\end{tabular}

Dalam pengujian ini digunakan uji mann-whitney untuk membandingkan jumlah penilaian IC antara pendidikan tinggi terbaik Indonesia dan pendidikan tinggi terbaik Malaysia menurut survey webomatric 2015. Uji mann-whitney merupakan salah satu uji non-parametrik yang sangat kuat dan merupakan uji alternatif dari uji parametrik t test. 
Tabel 3. Hasil Uji Statistik Mann-Whitney

\begin{tabular}{lr}
\hline & \multicolumn{1}{c}{ IC } \\
\hline Mann-Whitney U & 8,500 \\
Wilcoxon W & 23,500 \\
Z &,$- 84 \mathrm{I}$ \\
Asymp. Sig. (2-tailed) &, $40 \mathrm{I}$ \\
Exact Sig. [2*(I-tailed Sig.)] &, $42 \mathrm{I}^{\mathrm{b}}$ \\
\hline
\end{tabular}

Tabel 3 menjelaskan bahwa besarnya nilai $Z$ hitung adalah $-0,84 I$. Nilai Asymp. Sig. (2-tailed) pada penelitian ini yaitu 0,40I, sehingga dapat dikatakan bahwa pengungkapan IC pada official website antara pendidikan tinggi Indonesia dan Malaysia tidak terdapat perbedaan yang signifikan, dikatakan tidak terdapat perbedaan yang signifikan dilihat dari nilai Asymp. Sig. (2-tailed) pada penelitian ini > 0,05 yaitu 0,40I, sedangkan dapat dikatakan beda apabila nilai Asymp. Sig. (2-tailed) $<0,05$.

Tidak adanya perbedaan dari hasil uji mann-whitney tersebut dikarenakan pengungkapan IC pendidikan tinggi Indonesia dan Malaysia relatif sama, walaupun terdapat perbedaan tapi tidak terlalu signifikan dan persentase perbedaannya relatif kecil, perbedaan pengungkapan item IC pada pendidikan tinggi Indonesia dan Malaysia rata-rata hanya dalam bentuk pengungkapannya salah satunya adalah item dosen, telah banyak pendidikan tinggi di Indonesia mengungkapkan jumlah dosen mereka dalam bentuk grafik sedangkan pendidikan tinggi Malaysia hanya dalam bentuk narasi maupun numerik, hal inilah yang menyebabkan perbedaan jumlah nilai pengungkapan IC.

Kesadaran pendidikan tinggi di Indonesia maupun Malaysia terhadap pentingnya publikasi kegiatan dan pengungkapan informasi melalui website telah membuktikan keterbukaan pendidikan tinggi kepada publik. Secara umum tujuan dari website pendidikan tinggi adalah menginformasikan pada dunia luar yaitu masyarakat mengenai informasi akademik, hasil penelitian dan pengabdian, serta informasi umum mengenai pendidikan tinggi. Selain penelitian ilmiah dan pendidikan, yang merupakan inti dari kegiatan universitas adalah pelatihan, komersialisasi penelitian, transfer pengetahuan kepada masyarakat, layanan, dan layanan infrastruktur (OECD (1999)). Karena website merupakan media yang paling populer maka pendidikan tinggi di 
Indonesia dan Malaysia lebih aktif dalam memperbaharui website yang dimiliki dengan tujuan meningkatkan nilai tawar bagi pendidikan tinggi.

Keterbukaan Informasi Publik (KIP) telah diatur dalam undang-undang nomor I4 tahun 2008. Dalam hal tersebut yang dimaksud dengan informasi publik yaitu informasi yang dihasilkan, disimpan, dikelola, dikirim, dan diterima oleh badan publik yang berkaitan dengan penyelenggara dan penyelenggaraan negara atau badan publik yang berkaitan dengan kepentingan publik. Badan publik yang dimaksud yaitu lembaga eksekutif, legislatif, yudikatif, dan badan lain yang tugas pokoknya berkaitan dengan negara dan organisasi nonpemerintah yang seluruh atau sebagian dananya bersumber dari APBD, sumbangan masyarakat, dan luar negeri. Dengan Adanya UU KIP membuat pendidikan tinggi dituntut untuk lebih terbuka sebab sebab pendidikan tinggi berada dibawah pengelolaan negara, sehingga kinerja pendidikan tinggi dipantau negara.

Berdasarkan uraian diatas menunjukkan jika pengungkapan item IC pada pendidikan tinggi di Indonesia dan Malaysia tidak terdapat perbedaan yang signifikan. Dari analisis isi memang terdapat pebedaan jumlah nilai pengungkapan hal ini disebabkan oleh perbedaan bentuk pengungkapan, sebagian pendidikan tinggi sudah menyajikan pengungkapan dalam bentuk grafik sehingga nilainya lebih tinggi, sedangkan pendidikan tinggi yang lain hanya mengungkapkan dengan narasi sehingga nilai yang diberikan relatif lebih rendah.

\section{SIMPULAN}

Hasil analisis data menunjukkan bahwa pengungkapan IC pada pendidikan tinggi di Indonesia paling tinggi diungkapkan oleh Institut Teknologi Bandung dengan jumlah penilaian 62 atau $61 \%$, sedangkan pengungkapan terendah diungkapkan oleh Universitas Airlangga dengan jumlah penilaian 38 atau 37\%. Pengungkapan IC pada official website pendidikan tinggi Malaysia hanya ada satu pendidikan tinggi yang mengungkapkan $\geq 50 \%$ item IC nya yaitu University of Malaya dengan jumlah penilaian 62 atau $61 \%$. Empat pendidikan tinggi yang lain sebenarnya sudah cukup banyak mengungkapan item IC mereka tapi kebanyakan hanya dalam bentuk narasi sehingga nilai yang diberikan hanya satu, masih sangat sedikit pendidikan tinggi yang 
mengungkapkan item IC dalam bentuk grafik dan mendapat nilai empat itulah sebabnya jumlah penilaian menjadi relatif rendah.

Selanjutnya setelah dilakukan uji mann-whitney pada penelitian ini membuktikan bahwa tidak ada perbedaan yang signifikan antara pendidikan tinggi Indonesia dan Malaysia, tidak adanya perbedaan tersebut dikaenakan jumlah pengungkapan IC pendidikan tinggi Indonesia dan Malaysia relatif sama hanya berbeda dalam cara penyajian item yang diungkapkan.

\section{REFERENSI}

Bezhani, I. 20I0. "Intellectual capital reporting at UK universities". Journal of Intellectual Capital, Vol. II, No. 2, hlm: I79-207.

Cahyuni, I., I. Ulum, dan A. Prasetyo. 20I2. "Analisis Pengungkapan Intellectual Capital pada Official Website Peraih Qs Star di Indonesia 20II; Komparasi Antara Perguruan Tinggi Negeri (PTN) dan Swasta (PTS)". Artikel dipresentasikan pada Simposium Nasional Akuntansi \& Bisnis, di Bandung.

Cañibano, L., dan M. P. Sánchez. 2009. "Intangibles in universities: current challenges for measuring and reporting". Journal of Human Resource Costing \& Accounting, Vol. 13, No. 2, hlm: 93-104.

Cañibano, L., dan P. Sánchez. 2004. "Measurement, management and reporting on intangibles. State of the art". Accounting and Business Review, Vol. 3, No. I, hlm: 37-62.

Ghozali, I. 2006. Stattistik non-parametrik: Teori dan aplikasi dengan program SPSS. Semarang: Universitas Diponegoro.

Leitner, K.-H. 2002. "Intellectual Capital Reporting for Universities: Conceptual background and application within the reorganisation of Austrian universities". Artikel dipresentasikan pada The Transparent Enterprise. The Value of Intangibles, 25-26 November, di Madrid, Spain.

2004. "Intellectual capital reporting for universities: conceptual background and application for Austrian universities". Research evaluation, Vol. I3, No. 2, hlm: I29-I40.

OECD. 1999. Measuring Student Knowledge and Skills : A New Framework for Assessment.

Pulic, A. 1998. "Measuring the Performance of Intellectual Potential in Knowledge Economy". Artikel dipresentasikan pada the 2nd McMaster World Congress on Measuring and Managing Intellectual Capital, di Austria. 
Ramírez, Y. 2013. "Intellectual capital management and reporting in European higher education institutions". Intangible Capital, Vol. 9, No. I, hlm.

Ulum, I. 20II. "Konstruksi Komponen Intellectual Capital untuk Perguruan Tinggi di Indonesia". Unpublished Paper. Laporan Penelitian dibiayai oleh DPPM Universitas Muhammadiyah Malang, Malang.

- 2012. "Konstruksi Komponen Intellectual Capital untuk Perguruan Tinggi di Indonesia". Jurnal Reviu Akuntansi dan Keuangan, Vol. 2, No. 2, hlm: 25I-262.

2013. "iB-VAIC: Model Pengukuran Kinerja Intellectual Capital Perbankan Syariah di Indonesia". Inferensi (Terakreditasi Dikti), Vol. 7, No. I, hlm: I83204.

- 2014. "Extended VAIC Plus (EVAIC+); a Comprehensive Measurement Model of Intellectual Capital Performance". Artikel dipresentasikan pada Ist International Conference on Future Business Environment and Innovation, di Malang.

- 2015. Intellectual Capital: Model Pengukuran, Framework Pengungkapan, dan Kinerja Organisasi. Malang: UMM Press.

Ulum, I., I. Ghozali, dan A. Purwanto. 2014a. "Intellectual Capital Performance of Indonesian Banking Sector: A Modified VAIC (M-VAIC) Perspective". Asian Journal of Finance \& Accounting, Vol. 6, No. 6, hlm: I03-I 23.

- 2014b. "Konstruksi Model Pengukuran Kinerja dan Kerangka Kerja Pengungkapan Modal Intelektual". JAMAL (Jurnal Akuntansi Multiparadigma), Vol. 5, No. 3, hlm: 380-392.

Ulum, I., dan A. Juanda. 2016. Metodologi Penelitian Akuntansi. Yogyakarta: Aditya Media Publishing. 